\title{
QUANTITATIVE TRAIT LOCI ASSOCIATED WITH RESISTANCE TO GRAY LEAF SPOT AND GRAIN YIELD IN CORN
}

\author{
QTLs associados à resistência a cercosporiose e produção de grãos em milho
}

\author{
Adriano Delly Veiga ${ }^{1}$, Renzo Garcia Von Pinho ${ }^{2}$, Luciane Vilela Resende ${ }^{2}$, \\ Édila Vilela de Resende Von Pinho ${ }^{2}$, Márcio Balestre ${ }^{3}$, Laís Andrade Pereira ${ }^{4}$
}

\begin{abstract}
The main objectives of hybrid development programs include incorporating genetic resistance to diseases and increasing grain yield. Identification of Quantitative Trait Loci (QTL) through the statistical analysis of molecular markers allows efficient selection of resistant and productive hybrids. The objective of this research was to identify QTL associated with resistance to gray leaf spot and for grain yield in the germplasm of tropical corn. We used two strains with different degrees of reaction to the disease; the genotypes are owned by GENESEEDS Ltda, their $F_{1}$ hybrid and the $F_{2}$ population. The plants were evaluated for gray leaf spot resistance, for grain yield and were genotyped with 94 microsatellite markers. Association of the markers with the QTL was performed by single marker analysis using linear regression and maximum likelihood analysis. It was observed that the additive effect was predominant for genetic control of resistance to gray leaf spot, and the dominant effect in that of grain yield. The most promising markers to be used in studies of assisted selection are: umc2082 in bins 4.03 and umc1117 in bins 4.04 for resistance to gray leaf spot; for grain yield umc1042 in bins 2.07 and umc1058 in bins 4.11 .
\end{abstract}

Index terms: Maximum likelihood, microsatellites, regression.

\section{RESUMO}

A incorporação de resistência genética a doenças e o aumento na produtividade de grãos estão entre os principais objetivos dos programas de desenvolvimento de híbridos. A identificação de locos de caracteres quantitativos (QTL) por meio de análises estatísticas associadas a marcadores moleculares possibilita a rápida obtenção de híbridos resistentes e produtivos. Nesta pesquisa, objetivou-se identificar locos de caracteres quantitativos (QTL) associados com resistência à cercosporiose e com produção de grãos em germoplasma de milho tropical. Foram utilizadas duas linhagens contrastantes em níveis de reação à doença (genótipos pertencentes à GENESEEDS - Ltda), seu híbrido $F_{1}$ e a população segregante $F_{2}$. Essas plantas foram fenotipadas quanto à resistência a doença e quanto a produção de grãos e genotipadas com 94 marcadores de microssatélites. A associação dos marcadores ao QTL foi realizada por meio de análises de marcas individuais, utilizando as metodologias de regressão linear e análise da máxima verossimilhança. Observou-se que o tipo de efeito predominante no controle genético da resistência a cercosporiose foi o aditivo e para o controle genético da produção de grãos foi de dominância. Os marcadores microssatélites mais promissores para serem utilizados em estudos de seleção assistida para resistência a cercosporiose são umc2082 na posição 4.03 e umc1117 na posição 4.04 e para produção de grãos, umc1042 e umc1058 nas posições 2.07 e 4.11.

Termos para indexação: Máxima verossimilhança, microssatélites, regressão.

(Received in february 3, 2012 and approved in february 29, 2012)

\section{INTRODUCTION}

Though there is ample evidence that genetic breeding offers gains in grain yields of corn, edaphic and biological stress conditions may hamper the expression of the maximum genetic yield potential of cultivars. The widespread adoption of conservation practices to reduce soil erosion leads to higher levels of residues remaining on the soil surface, and continuous planting of susceptible maize cultivars has helped to spread the range and increased the incidence of gray leaf spot in the U.S. Corn
Belt (GORDON et al., 2006). In Brazil an increase in late growing season areas and no-till systems has been observed, which has led to the development of diseases (BRITO et al., 2007). Under these conditions, the pathogens that survive in the residues of the previous crop experience increase in their inoculum potential.

The genetic breeding of corn for traits resistant to biotic and abiotic stresses is of the utmost importance in ensuring the sustainable stability of grain yields. Recently in Brazil, gray leaf spot caused by the fungus Cercospora zeae-maydis $(\mathrm{Cz})$, has been considered one of the main

\footnotetext{
1Universidade Federal de Lavras/UFLA - Departamento de Agricultura/DAG - Cx. P. 3037 -37200-000 - Lavras - MG - Brasil - adrveiga@yahoo.com.br

2Universidade Federal de Lavras/UFLA - Departamento de Agricultura/DAG - Lavras - MG - Brasil

${ }^{3}$ Universidade Federal de Lavras/UFLA - Departamento de Ciências Exatas/DEX - Lavras - MG - Brasil

${ }^{4}$ Universidade Federal de Lavras/UFLA - Lavras - MG - Brasil
} 
corn crop diseases, especially in the southern interior of the country. The incorporation of genetic resistance to $\mathrm{Cz}$ is among the main objectives of hybrid development programs for regions where this disease is prevalent (POZAR et al., 2009). However, the development of cultivars for resistance to diseases is considered onerous and expensive as it involves various selection cycles.

Mapping and identification of Quantitative Trait Loci (QTL) with the use of molecular markers enables rapid development of resistant and high-yielding cultivars through marker assisted selection. Studies aimed at expanding our knowledge of the nature and magnitude of resistance gene effects are important for guiding research efforts into the introduction of favorable alleles in susceptible germplasms, and for maximizing the utilization of genetic variability (POZAR et al., 2009).

Inheritance studies have indicated that resistance to gray leaf spot is governed by a large number of genes of small effect, with the prevalence of additive effects. These QTL may be determined by using RFLP markers (SAGHAI MAROOF et al., 1996), microsatellites (JULIATTI et al., 2009 and ASEA et al., 2009), and by SNP (POZAR et al. 2009).

The most important trait for breeding programs is grain yield. This trait is controlled by many loci and its inheritance also has been studied through QTL mapping (LIMA, 2006; STUBER, 1992). Previous studies regarding both disease resistance and grain yield traits were not found.

The objective of this work was to identify microsatellite markers associated with QTL for gray leaf spot resistance and grain yield in tropical germplasm.

\section{MATERIAL AND METHODS}

This research was conducted in the Electrophoresis Laboratory (Seed Sector) and in the experimental area of the Agriculture Department at the Universidade Federal de Lavras, located at coordinates $21^{\circ} 14^{\prime} 30^{\prime \prime} \mathrm{S}$ and $45^{\circ} 00^{\prime} 10^{\prime}$ $\mathrm{W}$, and at an altitude of $918 \mathrm{~m}$. Under the Koppen climate classification, the local climate is Cwa type with an average annual temperature of $20.4^{\circ} \mathrm{C}$. The genotypes used belong to the breeding program of GENESEEDS Ltda, derived from Cateto and Caribean germplasm. Two lines, L30 (resistant parent) and L31 (susceptible parent), with contrasting reactions to gray leaf spot, the $F_{1}$ hybrid and the $F_{2}$ segregating population were used. Sowing was performed in November 2009 and field trials were carried out following regular cultural practices for corn growth.
For evaluation of severity of the disease $(\mathrm{Cz})$, each parent, $\mathrm{F}_{1}$ hybrid, and $\mathrm{F}_{2}$ progenies were arranged in $4 \mathrm{~m}$ rows with five seeds per meter. A visual evaluation of leaf areas affected by the disease was performed at 95 days after the emergence of the plants by means of a 1-9 scale (AGROCERES, 1996). Twelve plants per parental line and $\mathrm{F}_{1}$ and $240 \mathrm{~F}_{2}$ families were independently scored under natural infection epidemic and sampled for grain yield determination in three replications. Collection and manual shelling of the ears was performed, the water content was determined and corrected for $13 \%$ moisture content.

Analysis of variance was performed for the phenotypic data using Proc Glm, a part of the SAS program (SAS INSTITUTE, 2000). Each parental line, the $F_{1}$ hybrid and $F_{2}$ families were considered as generations. The number of plants for each generation was considered a treatment, with 20 plants for parental lines and hybrid and 240 plants for $\mathrm{F}_{2}$ per block. Treatments were decomposed by orthogonal contrasts, at a significance of 5\%. Using the values of variance of disease severity and grain yield, the components of variance and heritability were estimated according to Ramalho et al. (2008).

DNA extraction from plants was performed with $2 \%$ CTAB extraction buffer, as described by Cheung et al. (1993). About $2 \mathrm{~g}$ of young leaves were individually sampled without replications. Initially, the markers were used to verify polymorphism between the parental lines. For this study, 94 microsatellites were selected based on previous research (POZAR et al., 2009; ASEA et al., 2009; GORDON et al., 2006). The amplifications were performed with $20 \mathrm{ng}$ of DNA, $0.5 \mu \mathrm{M}$ of each primer, $100 \mu \mathrm{M}$ of each dNTP, 10 $\mathrm{mM}$ Tris- $\mathrm{HCl}$ (pH 8.6), $50 \mathrm{mM} \mathrm{KCl}, 2 \mathrm{mM} \mathrm{MgCl} 2$ and $1 \mathrm{U}$ of the enzyme Taq polymerase, in a total volume of $25 \mu \mathrm{L}$. After initial evaluation of the parental polymorphism, the polymorphic markers were used for genotyping 93 individuals of the $\mathrm{F}_{2}$ population, which were selected according to DNA quality.

Identification of QTL was performed by means of single marker analyses using the methodologies of individual linear regression, multiple linear regression and maximum likelihood analysis.

The individual linear regression was performed using phenotype data related to the genotype of each marker. Molecular data and the severity scores of the disease and the grain yield values were associated using Proc Reg (part of the SAS program, SAS Institute, 2000). Associations were considered significant with a probability level $\mathrm{P}<0.05$ using F-test, regarding $\mathrm{H}_{0}$ as the absence of QTL effect. The coefficient of determination $\left(\mathrm{R}^{2}\right)$ was interpreted as the estimate of the 
proportion of phenotypic variance explained for each marker. The frequency of recombination was estimated based on the average number of individuals by genotype and on the value of the F-test for each marker. Based on the estimates of the additive and dominant effects of the marker locus and the frequency of recombination, the additive and dominant effects for the QTL were calculated, following Schuster and Cruz (2008).

Multiple regression analysis was performed involving all the polymorphic markers between the parental lines, using Proc Reg. The genotypes of the markers were considered as regressors of the phenotypic values. The markers of greatest importance were selected by means of significant values from the partial $F$ test $(\mathrm{P}<0.05)$ and the percentage of variation explained by them was estimated by the partial coefficient of determination. Stepwise regression selection (DRAPER; SMITH, 1981) was applied to obtain a better estimate of the genotype values of the QTL and the percentage of phenotypic variation, as well as to eliminate markers of marginal effect.

The association of the markers with the QTL by means of maximum likelihood was performed using the procedure Proc Iml (SAS program). The mean values, additive and dominant effects, variance, and frequency of recombination were estimated by iterative processes in the expectation-maximization (EM) algorithm, to find the maximum likelihood. For that purpose, a mixture model was used, conditioned on joint segregation of the marker and of a supposed QTL, based on its frequency of recombination (LIU; ZENG, 2005).

The statistical test used to verify if there is an association between marker and a QTL was the likelihood ratio (LR) following a chi-square distribution. In this test, the values found for the ratio between the hypotheses $\mathrm{H}_{0}$ (marker and QTL are not associated or absence of the QTL effect) and $\mathrm{H}_{1}$ (marker and QTL are associated or presence of QTL effect) was observed. In which, $\mathrm{H}_{0}: \mu \mathrm{MM}=\mu \mathrm{Mm}=$ $\mu \mathrm{mm}$ with $\mathrm{r}=0.5$ and $\mathrm{H}_{1}: \mu \mathrm{MM} \neq \mu \mathrm{Mm} \neq \mu \mathrm{mm}$ with an additive effect different of a dominant effect $(a \neq d)$. According to the expression:

$L R=-2 \ln \left[\frac{L(r=0.5)}{L\left(\mu_{1}, \mu_{2}, \mu_{3}, \sigma_{2}, r ; y_{i}\right)}\right]$

In which:

LR: likelihood ratio;

$\mathrm{L}(\mathrm{r}=0.5)$ : maximum-likelihood estimation for absence of QTL effect;
$\mathrm{L}\left(\mu_{1,} \mu_{2}, \mu_{3}, \sigma^{2}, \mathrm{r}, \mathrm{yi}\right):$ maximum-likelihood estimation for presence of QTL effect;

$\mu_{1}: \mu \mathrm{MM}$ : phenotypic mean in reference to the dominant genotype;

$\mu_{2}: \mu \mathrm{Mm}$ : phenotypic mean in reference to the heterozygous genotype;

$\mu_{3}: \mu \mathrm{mm}$ : phenotypic mean in reference to the recessive genotype;

$\sigma^{2}$ : residual variance

$\mathrm{r}$ : frequency of recombination

$\mathrm{y}_{\mathrm{i}}$ : vector with phenotypic value of the individuals.

Nevertheless, in a mixture model, the asymptotic approximation is not guaranteed and, for that reason, $\mathrm{a}_{0}$ empirical distribution was constructed through permutations. Three thousand permutations were used to reconstruct the distribution of the LR variable and determine the critical value (alpha $=0.05$ ), which allows us to declare the existence of a QTL associated with the marker (CHURCHILL; DEORGE, 1994). In this analysis, the grain yield values were expressed in $\mathrm{kg} / \mathrm{plant}$.

\section{RESULTS AND DISCUSSION}

Most plants had moderate resistance to gray leaf spot (GLS), with scores between 4 and 5 and grain yield close to $105.2 \mathrm{~g} /$ plant. In the phenotypic analysis a coefficient of variation similar to the value found by Juliatti et al. (2009) for gray leaf spot was observed, and a smaller coefficient for grain yield compared to results found by Lima (2006). For both traits, there were significant differences among generations, treatment within generations and high significant differences for the contrasts (Table 1). The significant contrast between parents $\left(\mathrm{P}_{1}\right.$ vs $\left.\mathrm{P}_{2}\right)$ and between parents and progenies (Ps vs $\mathrm{F}_{2}$ ) demonstrated that from these contrasting lines, variability could be created in a segregating generation used to identify the molecular markers associated to QTL for the traits.

For gray leaf spot severity, the genetic variance was 0.619 and the environmental variance was 0.142 , for grain yield the values found were 904.8 and 272.48. The high estimate of heritability for gray leaf spot severity $(81.3 \%)$ is within the values found in previous researches (CLEMENTS et al., 2000, GORDON et al. 2006). The value of heritability found for grain yield $(76 \%)$ is near the values observed by Lima (2006). According to Silva and Vencovsky (2002) simulating different QTL detection methodologies can increase the test's power of detectionwhen the trait in question has higher heritability values. 
Table 1 - Variance analysis for Gray leaf spot (GLS) severity and grain yield.

\begin{tabular}{lccc}
\hline \multirow{2}{*}{ SV } & \multirow{2}{*}{ DL } & \multicolumn{2}{c}{ MS } \\
\cline { 3 - 4 } \cline { 3 - 4 } Block & \multicolumn{1}{c}{ GLS } & Grain Yield \\
\hline Generation & 2 & $6.93^{*}$ & 42.67 \\
Treatment(Generation) & 296 & $11.43^{*}$ & $118444.9^{*}$ \\
$\mathrm{P}_{1}$ vs $_{2}$ & 1 & $143.27^{*}$ & $182426.03^{*}$ \\
Ps vs F $_{1}$ & 1 & $180.3^{*}$ & $148965.05^{*}$ \\
Ps vs F & 1 & $477.19^{*}$ & $245274.9^{*}$ \\
Residue & 598 & 1.44 & 54.34 \\
Average & & 4.11 & 105.2 \\
CV(\%) & & 29.15 & 9.0 \\
$\mathrm{~h}^{2}$ & & 81.3 & 76 \\
\hline
\end{tabular}

* significant to $5 \%$ probability.

Of the 94 markers used in this study, 23 were polymorphic between the parental lines, 53 were monomorphic and 18 failed.

By using individual linear regression, five of the 23 polymorphic markers between the parents proved to be associated with QTL that are possibly related to the control of gray leaf spot resistance, at $\mathrm{p}<0.05$. It was observed that the umc2082 marker presented a greater significance of association with a QTL and greater explanation of phenotypic variance in relation to the other markers (Table 2).

Considering single marker analysis, the fact could have occurred due to the marker being nearer the QTL of resistance, which could be verified by the distance or frequency of recombination. As the variation of the quantitative trait is explained by the marker due to its linkage with the QTL, the greater the intensity of linkage, the greater the variance among the genotypes of the markers will be (BERNARDO, 2002).

The values of $\mathrm{R}^{2}$ for each QTL associated with the marker are among the values already reported in the literature and within the values found for quantitative traits. However, in the detection method used, in addition to the QTL that is being marked, others may occur nearby and affect the means of the genotypes, overestimating the effect of the QTL. That way, a gene block would be marked and not only a single QTL. Together, the QTL explained $54.7 \%$ of the phenotypic variation. Similar results were found in previous research, as reported by Clements et al. (2000) who observed 5 QTL explaining 58.7\% of the variation, and by Gordon (2004), who observed QTL also in chromosomes 2 and 4 , explaining $54 \%$ of the phenotypic variation. The total phenotypic variation $\left(\mathrm{R}^{2}\right)$ was observed as being smaller than the heritability regarding the phenotypic data.

The predominance of additive gene effects was observed in resistance to gray leaf spot, as recorded in Saghai and Maroof et al. (1996), Pozar et al. (2009) and Juliatti, et al. (2009). These effects reduce the severity of the disease (negative signal). Only the QTL associated with the marker bnlg1250 presented a positive dominant effect, that is, increasing the severity of the disease (Table 3).

The negative signal of the significant additive effect also indicates that the locus of resistance retains a contribution from resistant parent L30, since this effect represents a contrast between the means of the dominant and recessive genotypes, based on the lower scores attributed to the resistant individuals.

Table 2 - List of microsatellite markers associated with resistance to gray leaf spot and grain yield, their position in the genome, frequency of recombination, variance and significance obtained in analysis of individual linear regression.

\begin{tabular}{ccccccc}
\hline Marker & Position & Fc & Pr>F & Var. & $\mathrm{R}^{2}(\%)$ & FR \\
\hline umc $1117^{(1)}$ & 4.04 & 6.41 & 0.0025 & 4.19 & 12.5 & 0.29 \\
umc 2082 & 4.03 & 9.5 & 0.0002 & 3.96 & 17.4 & 0.25 \\
bnlg $1265^{(1)}$ & 4.05 & 5.57 & 0.0052 & 4.26 & 11.02 & 0.27 \\
bnlg $1520^{(1)}$ & 2.09 & 2.95 & 0.054 & 4.50 & 6.15 & 0.35 \\
bnlg 1250 & 10.05 & 3.79 & 0.026 & 4.41 & 7.7 & 0.35 \\
umc 2082 & 4.03 & 3.33 & 0.048 & 1314 & 6.5 & 0.35 \\
umc 1058 & 4.11 & 4.39 & 0.015 & 1285 & 8.8 & 0.31 \\
umc 1042 & 2.07 & 4.09 & 0.019 & 1288 & 8.3 & 0.32 \\
\hline
\end{tabular}

1: marker associated with gray leaf spot resistance. 2 : marker associated with grain yield.

Var.: variance or residual error.

Ciênc. agrotec., Lavras, v. 36, n. 1, p. 31-38, jan./fev., 2012 
Table 3 - Frequency of recombination, estimates of the additive and dominance effect of the marker locus $\left(\beta_{1}, \beta_{2}\right)$ and of the QTL locus $(\mathrm{a}, \mathrm{d})$ associated with resistance to gray leaf spot and grain yield in corn, by means of individual linear regression.

\begin{tabular}{cccccccc}
\hline Marker & FR & $\beta_{1}$ & $\beta_{2}$ & $\mathrm{a}$ & $\mathrm{d}$ & $\mathrm{d} / \mathrm{a}$ & Action $^{(3)}$ \\
\hline umc $1117^{(1)}$ & 0.29 & -1.129 & -0.162 & $-2.72^{*}$ & -0.945 & 0.35 & PD \\
umc $2082^{(1)}$ & 0.25 & -1.444 & -0.454 & $-2.97^{*}$ & -1.924 & 0.65 & PD \\
bnlg $1265^{(1)}$ & 0.27 & -1.001 & 0.595 & $-2.18^{*}$ & 2.8 & 1.28 & OD \\
bnlg $1520^{(1)}$ & 0.35 & -0.657 & 0.505 & $-2.22^{*}$ & 5.3 & 2.56 & OD \\
bnlg $1250^{(1)}$ & 0.34 & -0.412 & 0.971 & -1.35 & $10.5^{*}$ & 7.7 & OD \\
umc $2082^{(2)}$ & 0.35 & -14.11 & -9.76 & $-46.5^{*}$ & -101.6 & 2.18 & OD \\
umc $1058^{(2)}$ & 0.32 & 10.8 & 14.55 & 30.68 & $117.5^{*}$ & 4.48 & OD \\
umc $1042^{(2)}$ & 0.32 & -0.71 & 14.6 & -2.08 & $124.9^{*}$ & 60.08 & OD \\
\hline
\end{tabular}

1: marker associated with gray leaf spot resistance. 2: marker associated with grain yield. 3: type of gene action: PD - partial dominance, OD - overdominance.

* significant to $5 \%$ probability.

For grain yield, three possible QTL associated with the polymorphic markers, were found, presenting F-test probability values below 0.05 (Table 2). Two QTL were found in chromosomes 2 and 4 which, relatively, explained a good proportion of phenotypic variance. Using composite interval mapping, Lima (2006) found stable QTL among environments in these chromosomes, with $\mathrm{R}^{2}$ values from 0.3 to $20.6 \%$.

As to the degree of dominance, only the overdominance gene action was observed (Table 3 ). This type of effect was previously reported in mapping and identification studies for grain yield (LIMA, 2006).

Multiple regression analysis for disease resistance identified six markers linked to QTL participating in the genetic control of this trait (Table 4). Five of them, umc2082, umc1117, umc1058, bnlg1250 and bmc1714, tended to reduce (negative signal) the severity of the disease due to a significant additive effect and a QTL which tends to increase (positive signal) due to a dominant effect present in the model.

In relation to individual linear regression, this methodology removed one marker, and two were added in genetic control of the trait. The $\mathrm{R}^{2}$ values found by multiple linear regression explained a total of $44.2 \%$ of the phenotypic variation and presented greater amplitude (3.15 - 16.4\%) when compared to those found in individual linear regression. In both regression methodologies the bnlg1520 marker was found on chromosome 2. Gordon (2004) found the same marker associated with a QTL for resistance to gray leaf spot using single analysis by Anova, in two generations and different locations.
Table 4 - Summary of the multiple regression analysis for resistance to gray leaf spot and grain yield using the Stepwise process for selection of markers.

\begin{tabular}{|c|c|c|c|c|}
\hline Marker & Estimates & Partial $\mathrm{R}^{2}$ & Error & F test* \\
\hline intercept $^{(1)}$ & 3.86 & & 0.242 & 253.8 \\
\hline umc $2082^{(1)}$ & $-1.30 \mathrm{a}$ & 0.164 & 0.283 & 21.3 \\
\hline umc1117 & $-0.756 a$ & 0.086 & 0.266 & 8.03 \\
\hline umc1058 $8^{(1)}$ & $-0.819 a$ & 0.068 & 0.266 & 9.47 \\
\hline bnlg1250 & $0.953 \mathrm{~d}$ & 0.043 & 0.355 & 7.21 \\
\hline bmc1714 ${ }^{(1)}$ & $-0.916 \mathrm{a}$ & 0.032 & 0.282 & 10.59 \\
\hline bnlg1520 & $-0.785 a$ & 0.049 & 0.284 & 7.62 \\
\hline intercept ${ }^{(2)}$ & 87.56 & & 6.58 & 174 \\
\hline umc $1042^{(2)}$ & 21.48 & 0.082 & 7.23 & 8.3 \\
\hline umc $1058^{(2)}$ & 17.06 & 0.054 & 7.28 & 5.49 \\
\hline
\end{tabular}

1: marker associated with gray leaf spot resistance. 2: marker associated with grain yield.

*Significant to the level of $5 \%$ probability by the $\mathrm{F}$ test.

Based on the data evaluated through this methodology, two QTL were found for grain yield, both contributing to an increase in the trait with dominance effects (Table 4). The QTL associated with the marker umc1042 presented a greater estimated genotypic value and a greater proportion of the phenotypic variation. Jointly, the QTL explained $13.6 \%$ of the phenotypic variation, a value close to that found when simple linear regression was used to verify the association and effect of the markers to QTL.

Using different types of regression analysis, coinciding results of the markers associated with QTL 
were found and similar genetic effects for resistance to the disease, however with lower values in the multiple regression. In relation to grain yield, distinct and superior effects were observed when analysis was performed by means of individual regression. These values may be overestimated by the methodology used to calculate the effects of the QTL based on the effects of the marker locus. Multiple linear regression analysis presents the markers associated with the QTL present in genetic control of the trait, as well as the type of its effects present in the final model, in a more rapid and precise manner.

According to Silva and Vencovsky (2002), the procedure based on multiple regression is more powerful in identifying the markers associated with QTL than the procedures based on individual tests, like simple linear regression, mainly when traits of low heritability and small numbers of individuals are evaluated. According to the authors, the power of the test is related to the probability of rejecting a hypothesis $\mathrm{H}_{0}$. Comparing the two types of regressions, greater $\mathrm{F}$ values calculated for each marker were observed due to lower residual variance when using multiple regression.

Using the maximum likelihood methodology, three of the 23 polymorphic markers among the parental lines were observed as presenting a significant association with the QTL which control resistance to gray leaf spot. The analyses with these markers presented maximum likelihood ratios (LR) above the critical value established in distribution of $\mathrm{H}_{0}$ considering an alpha of $5 \%$, thus rejecting the hypothesis of null effect and presenting (a) and (d) values (additive and dominance effects) different from zero.

In Table 5, markers associated with QTL are presented for resistance to gray leaf spot. These parameters were obtained after stationarity of the EM Algorithm.

For the QTL found, there is the predominance of the additive effects and they act in the sense of reducing the disease (negative signal of the additive parameter), with greater reduction of the QTL associated with the marker umc2082. The predominance of the additive effects has been observed by many studies related to controlling resistance to gray leaf spot in corn, such as the study performed by Clementes et al., (2000), who found 5 consistent QTL in the environments with additive effects in chromosomes $1,2,5$ and 7 .

In all methodologies the umc1117 and umc2082 markers were found to be associated with resistance to gray leaf spot. The markers on chromosome 4 could be associated to the same QTL.

For grain yield, of the 23 polymorphic markers among the parents, two of these were observed to be significantly associated with QTL present in the genetic control of the trait. Table 5 shows the markers associated with the QTL that control grain yield. Both the QTL presented a small value of frequency of recombination, being situated extremely close to markers. There was predominance of the dominance effects that were significant and acted to increase grain yield, with greater genetic effect observed for the QTL associated with the umc1042 marker. These same markers were also identified in multiple regression analysis.

In relation to the type of genetic action, overdominance was observed for the QTL associated with the umc1042 and umc1058 markers, results also observed in linear regression analysis and in previous studies such as Lima (2006) that found five QTL associated to a degree of dominance indicating overdominance.

Table 5 - List of microsatellite markers associated with resistance to gray leaf spot and grain yield, information regarding means, additive (a) and dominance (d) effects, degree of dominance (d/a), variance, percentage of recombination (r), maximum likelihood ratio (LR) and their probability.

\begin{tabular}{cccccccccc}
\hline Marker & means & $\mathrm{a}$ & $\mathrm{d}$ & $\mathrm{d} / \mathrm{a}$ & action $^{(3)}$ & Var. & $\mathrm{r}$ & LR & Critical Ho \\
\hline${\text { umc1 } 117^{(1)}}^{(1)}$ & 4.52 & $-2.13^{*}$ & -1.7 & 0.78 & PD & 0.93 & 0.36 & 47.8 & 32.7 \\
${\text { umc } 2082^{(1)}}^{4}$ & 4.54 & $-2.16^{*}$ & -1.69 & 0.79 & PD & 0.89 & 0.31 & 52.2 & 41.7 \\
${\text { umc } 1058^{(1)}}_{\text {umc } 1042^{(2)}}^{4.67}$ & $-1.91^{*}$ & -1.75 & 0.92 & CD & 1.59 & 0.42 & 30.9 & 30.1 \\
umc $1058^{(2)}$ & 0.096 & -0.007 & $0.022^{*}$ & 31.43 & OD & 0.0012 & 0.0007 & 8.10 & 6.9 \\
\hline
\end{tabular}

1: marker associated with gray leaf spot resistance. 2: marker associated with grain yield.

3: type of gene action: PD - partial dominance, CD - complete dominance, OD - overdominance.

* significant to $5 \%$ probability. 
Despite there being agreement about the markers linked with QTL present in genetic control of the traits evaluated, as well as similarity in the values of some parameters like genetic effects, a difference was observed in the number of markers connected to QTL for resistance to gray leaf spot in the analysis by means of maximum likelihood. It may be related to the conditional probabilities calculated for each phenotype presenting the possible genotypes of the QTL, a step performed in this analysis through iterative process within the EM algorithm. It may also be observed that the residual variance in which the hypothesis $\mathrm{H}_{0}$ is tested was smaller than the values observed in linear regression, increasing the power of detection in the test.

Precision in detection of association between a QTL and the marker has frequency of recombination as one of the principal factors (BORÉM; CAIXETA, 2009). This priori information was inserted in the likelihood function (LR), thus the probability of association between marker and QTL is conditional on the frequency of recombination. The existence of significant QTL indicates these genomic regions as possible new tools for marker assisted selection in maize breeding programs, but for that, they need to be studied in different environments.

\section{CONCLUSIONS}

The most promising markers to be used in studies of assisted selection are umc2082 and umc1117 for gray leaf spot resistance and umc1042 and umc1058 for grain yield.

The type of predominant effect for control of resistance to gray leaf spot is the additive and for genetic control of grain yield is the dominant effect.

\section{ACKNOWLEDGEMENTS}

To Conselho Nacional de Desenvolvimento Científico e Tecnológico (CNPq) and Fundação de Amparo à Pesquisa do Estado de Minas Gerais (FAPEMIG) for financial support.

\section{REFERENCES}

AGROCERES. Guia Agroceres de Sanidade. São Paulo: Sementes Agroceres, 1996. 72 p.

ASEA, G. et al. Validation of consensus quantitative trait loci associated with resistance to multiple foliar pathogens of maize. Phytopathology, v. 99, n. 5, 2009.

BERNARDO, R. Breeding for quantitative traits in plants. Minnesota, Stema Press. 2002.
BOREM, A.; CAIXETA, E.T. Marcadores Moleculares. 2 ed. Viçosa, UFV.2009. 532p.

BRITO, A.H. et al. Efeito da cercosporiose no rendimento de híbridos comerciais de milho.

Fitopatologia Brasileira, v. 32, p. 18-25, 2007.

CHURCHILL, GA.; DEORGE, R.W. Empirical threshold for quantitative trait mapping. Genetics, v.138, p.963-971, 1994.

CHEUNG, W.Y.; HUBERT, N.; LANDRY, B.S. A simple and rapid DNA microextration method for plant, animal, and insect suitable for RAPD and other PCR analyses. Technical Tips, v. 3, p.69-70, 1993.

\section{CLEMENTS, M.J.; DUDLEY, J.W.; WHITE, D.G.}

Quantitative trait loci associated with resistance to gray leaf spot of corn. Phytopathology. v.90, n.9, p.1018-1025, 2000.

DRAPER, N.R.; SMITH, H. Applied regression analysis. 2. ed. New York: J. Wiley, 1981. 709 p.

GORDON, S.G.; LIPPS. P.E.; RICHARD, R.C. Heritability and components of resistance to Cercospora zeamaydis derived from mayze inbred VO613Y.

Phytopathology.v.96, n.6, 2006.

GORDON, S.G. et al. 2004. Linkage of molecular markers to Cercospora zea-maydis resistance in maize. Crop Science 44:628-636.

JULIATTI, F.C. et al. Genetic mapping for resistance to gray leaf spot in maize. Euphytica, v.169, n.2, p.227-238, 2009.

LIMA, M.L.A. et al. Mapping QTL for grain yield and plant traits in a tropical maize population. Molecular Breeding, v. 17, p. 227-239, 2006.

LIU, Y.; ZENG, Z.B. Mixture model equations for markerassisted genetic evaluation. J. Anim. Breed. Genet. 122 (2005) 229-239.

POZAR, G. et al. Mapping and validation of quantitative trait loci for resistance to Cercospora infection in tropical maize (Zea mays L.). Theoretical and Applied Genetics, v.118, n. 3, p. 553-564, 2009.

RAMALHO, M.A.P.; SANTOS, J.B.; PINTO, C.A.B.P. Genética na Agropecuária. Lavras:Ed.UFLA, 2008. 464p. 
SAGHAIMARROF, M.A. et al. Identification of quantitative trait loci controlling resistance to gray resistance to gray leaf spot disease in maize. Theoretical and Applied Genetics, Berlin, v. 93, n. 4, p. 539-546, Sept. 1996.

SAS Institute (2000). Version 9.0. (SAS Institute Inc., Cary, NC).

SCHUSTER, I.; CRUZ, C.D. Estatística genômica: aplicada a população derivadas de cruzamentos controlados. Viçosa: UFV, 2008. 568p.
SILVA, H.D.; VENCOVSKY, R. Poder de detecção de "quantitative trait loci", da análise de marcas simples e da regressão linear múltipla. Scientia Agricola, v.59, n.4, p.755-762, out./dez. 2002.

STUBER, C. W. et al. Identification of genetic factors contributing to heterosis in a hybrid from two elite maize inbred lines using molecular markers. Genetics, Austin, v. 132, n. 3, p. 823-839, Nov. 1992. 